\title{
Drying and Rehydration Kinetics of Noodles
}

\author{
Takenobu OGAWA \\ Division of Food Science and Biotechnology, Graduate School of Agriculture, Kyoto University, \\ Sakyo-ku, Kyoto 606-8502, Japan
}

\begin{abstract}
Drying is the oldest method for preserving food, and rehydration is one of the simplest methods of cooking. The behavior of water transfer inside foods during the drying and rehydration processes varies depending on the manufacturing and cooking conditions, respectively, and the food quality is strongly affected by the behavior. Existing manufacturing and cooking processes, which have relied on great experience and build through trial and error, cannot quickly and accurately respond to the diverse demands of recent years, such as health consciousness and insatiable pursuit for palatability. Therefore, the theoretical study that enables rational food production has been strongly demanded. However, the phenomena and mechanisms of water transfer and their effects on the quality are not well understood. Focusing on the pasta with relatively simple composition, we have elucidated the phenomenon and its mechanism of water transfer occurring during drying and rehydration processes, and also investigated the effect of the water transfer on pasta quality. This review provides the overview of our findings.
\end{abstract}

Keywords: drying, rehydration, noodle, pasta

1. 緒

言

食品製造に打ける乾燥は，最も古い歴史をもつ食品 の保存法であり，茹でること(吸水) は，最も簡便な 調理法の 1 つである. 乾燥過程および吸水過程におけ る食品中の水の移動挙動は, 製造時および調理時の条 件によって大きく異なり，その挙動により，食品の品 質は大きな影響を受ける。経験と試行錯䛊に多くを頼っ てきた既存の製造法では，近年の健康志向や美味しさ への飽くなき追求といった多様な要求に対して，迅速 かつ的確に応えることが困難である。そのため，合理 的な食品製造を可能にする体系的な理論研究が強く求 められてきた. しかし, 水の移動現象と移動機構, そ れらが食感などの品質に及ぼす影響については，必ず しも十分に解明されていないように思われる。筆者ら は，粗挽きの小麦粉であるデュラムセモリナのみから なり, 組成が単純なパスタを研究対象として, 乾燥お よび吸水過程で生起する水の移動現象とその機構, そ

(受付 2020 年 2 月 13 日，受理 2020 年 2 月 27 日)

干606-8502 京都府京都市左京区北白川追分町

$\dagger$ Fax: 075-753-6285, E-mail: ogawat@kais.kyoto-u.ac.jp
して水の移動挙動が品質に及ぼす影響を明らかにして きた。本論文では，湎の乾燥挙動，デジタルカメラを 用いた麺の特性評価, 麺の吸水挙動, 乾燥打よび吸水 が麺の品質に及ぼす影響の順番に，これまでに得られ た筆者らの知見について解説する.

\section{2. 麺 の 乾 燥}

\section{1 水分収着等温線と水の部分モル体積}

水分収着等温線は，ある温度における水分活性と食 品素材の含水率との関係を表し, 水分子と食品素材の 間の相互作用を反映する。そして，水分収着挙動の温 度依存性より，熱力学的な特性を知ることができる. パスタを乾燥させる伝統的なプロセスでは, 乾燥空気

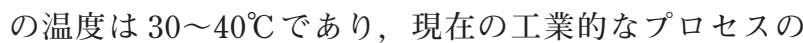
最大乾燥温度は $80 \sim 95^{\circ} \mathrm{C}$ であ。したがって，多様な パスタの乾燥プロセスを合理的に設計するには，パス タの原料であるデュラムセモリナの水分収着等温線が 広範囲の温度で必要となる。デュラムセモリナの水分 収着等温線は，多くの食品と同様，GuggenheimAnderson-de Boer (GAB) 式で良く表現できる（Fig. 1) [1]. すなわち，低い水分活性においては，デュラムセ 


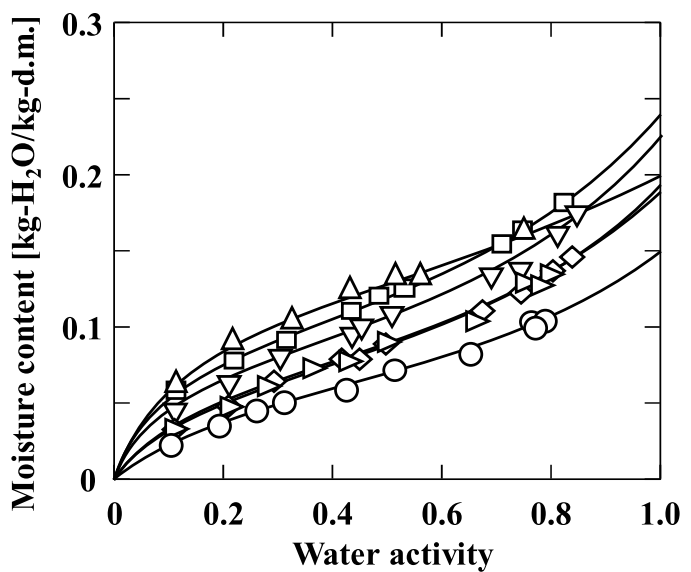

Fig. 1 Desorption isotherms of water onto durum wheat flour at $(\triangle) 30^{\circ} \mathrm{C},(\square) 40^{\circ} \mathrm{C},(\nabla) 50^{\circ} \mathrm{C},(\diamond) 60^{\circ} \mathrm{C},(\triangleright)$ $70^{\circ} \mathrm{C}$, and $(\bigcirc) 80^{\circ} \mathrm{C}$. Curves are calculated to best-fit the observed moisture contents to the GAB equation.

モリナの表面に水分子が単層を形成し，水分活性が高 くなると水分子の吸着が多層となり，さらに高い水分 活性ではデュラムセモリナと水分子の相互作用は弱ま り，細孔が水で埋まると考えられる.

水分収着等温線の他に，食品素材と相互作用してい る水の特性を調べる手法として，ディラトメトリ法が 挙げられる。この手法は，一定温度条件下で，非常に 少量の水を食品素材に加えた際に，その食品素材の体 積変化から水の部分モル体積を求めるものであり, 測 定には，上部に細いガラス管を有し，側方からシリン ジで水を挿入できる孔をもつガラス製のフラスコを用 いる (Fig. 2 inset)。まず，このガラス製のフラスコに， よく乾燥させたデュラムセモリナを入れて， ドデカン で容器を満たす。そして，一定温度に保ちながら，側 部からシリンジで少量の水（物質量 $\Delta n$ ）を入れ，体積

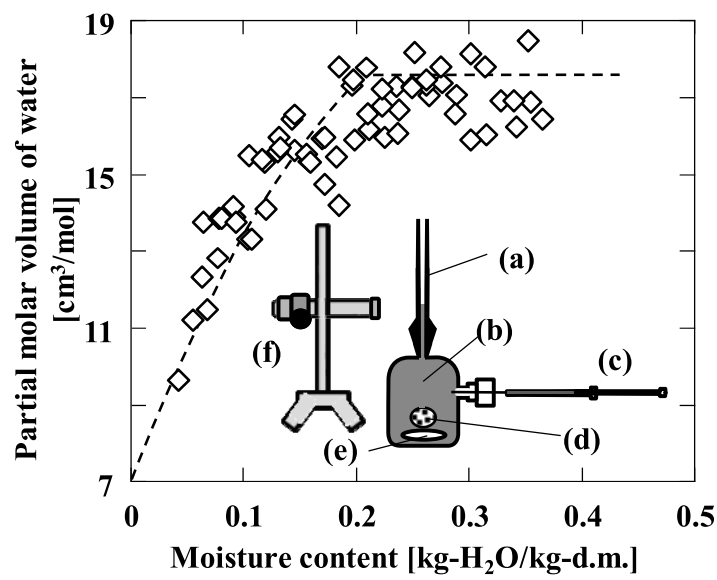

Fig. 2 Partial molar volume at $25^{\circ} \mathrm{C}$ of water sorbed to the durum wheat flour for various moisture contents. Inset: Schematic diagram of the equipment used for dilatometry: (a) capillary, (b) dodecane, (c) glass syringe with water, (d) durum wheat flour, (e) stirrer, and (f) casetometer.
変動がなくなったのを確認した後, 加水前後の体積増 加量 $(\Delta V)$ 加 近似的に見かけの水の部分モル体積 $(\Delta$ $V / \Delta n)$ を求めていく（Fig. 2) [2]．通常，他の異なる 物質から力を受けていない水（バルクの水）は， $1 \mathrm{~mol}$ で約 $18 \mathrm{~cm}^{3}$ である.しかし，水がデュラムセモリナに 単分子層吸着している領域では，非常に強く双方が作 用しているため, 約 $9 \mathrm{~cm}^{3} / \mathrm{mol}$ とバルクの半分程度で あった，その後，水を少しずつ加えていくと，吸着が 単分子層から多分子層へと移行し，水の部分モル体積 は徐々に増大した。そして，含水率が約 $0.2 \mathrm{~kg}-\mathrm{H}_{2} \mathrm{O} /$ kg-dry matter 以降で一定となった。つまり，デュラム セモリナ内の細孔を埋めるような水は，バルクの水と

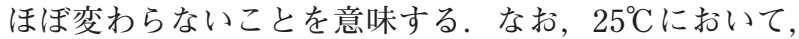
デュラムセモリナがガラス状態からラバー状態に転移 する際の含水率 [3] は, 約 $0.2 \mathrm{~kg}-\mathrm{H}_{2} \mathrm{O} / \mathrm{kg}-$ d.m. であり, 興味深い.

\section{2 熱重量分析による乾燥挙動の解析}

乾燥がごのように進行し，いつ終わるのかを予測す ることは，食品を製造するうえで重要であり，乾燥挙 動を記述するモデルは非常に多く提案されている。一 方で，それらのモデルを用いて予測するためには，種々 の物性值が必要となる。これらの物性值は，論文など の文献を参考する場合も多いが，より精度よく予測す るには，少なくとも実験室規模の乾燥装置を用いて実 測することが不可欠であり，それには多量の試料を要 する、筆者らは，数十ミリグラムという少量のスケー ルで測定を行う，熱重量測定 (Thermogravimetry: TG）に着目し，パスタの乾燥時の含水率の変化を高精 度に予測する手法を開発した [4]。なお，TG は試料を 一定の速度で加熱や冷却，あるいは一定の温度で保持 したときの試料の重量変化を測定するもので，一般的 には，気固反応や結晶水の定量など，熱反応プロセス の分析に用いられる。

まず，加水したデュラムセモリナをアルミ製の容器 に圧入して，疑似的なパスタ試料を作製した。この際， Fig. 3 の内図に示すようにガラスシリンジを用いること で，押し固める圧力を調節することができる。このよ うに作製したパスタ試料の重量を一定温度，一定湿度 の条件で TG を用いて測定した。湿度の調節は，TG 装 置の測定部に，飽和塩溶液中でバブリングさせた空気 を送り込み行った。温度を一定速度で上げながら測定 する，定速昇温条件での TG 解析も実施したが [5]，本 稿では割愛する，乾燥特性曲線は，試料の含水率に対 して乾燥速度をプロットしたものであり，重要な情報 を得ることができる。午の一例を Fig. 3 に示す．本実 験に打いては，試料の量が少ないこともあり，材料予 熱期間はみられず，乾燥速度が一定の定率乾燥期から 始まった。この期間に，約 $20 \%$ 程度の水が蒸発するこ 


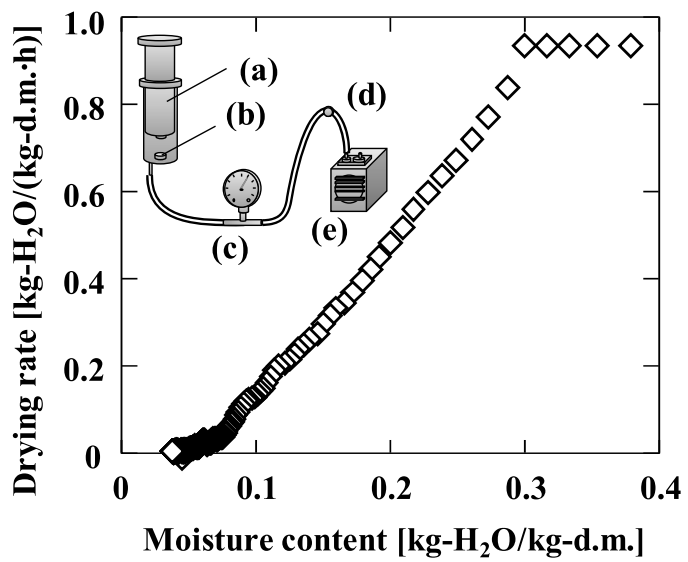

Fig. 3 The drying characteristic curve obtained by thermogravimetry at $90^{\circ} \mathrm{C}$ and $20.6 \% \mathrm{RH}$.

Inset: Schematic diagram of the equipment used for sample press: (a) glass syringe, (b) sample, (c) pressure gauge, (d) variable throttle, and (e) vacuum pump.

とがわかった，その後，含水率の低下にともない乾燥 速度が低下する減率乾燥期に移行した。食品の乾燥を 予測する多くのモデルでは，定率乾燥期を考慮せず， はじめから減率乾燥期と見なしているものが多いが, 筆者らは，定率乾燥期を考慮して，パスタの乾燥挙動 を記述するための簡易的なモデルを提案した [4]. な扔 このモデルでは，以下の 3 つのことを仮定している. (1)パスタ内部での伝熱は速く，温度は一様である。(2) 物質移動係数は含水率に依存しない. (3)乾燥に伴う収 縮は無視できる。そうすると，定率乾燥期における乾 燥速度，ならびに減率乾燥期に打ける含水率の変化量 はそれぞれ式(1) および式 (2)で表される.

$$
\begin{gathered}
R_{\mathrm{w}}=\frac{w}{S}\left(-\frac{\mathrm{d} X}{\mathrm{~d} t}\right) \\
\frac{\mathrm{d} X}{\mathrm{~d}\left(t / L^{2}\right)}=-k\left(X-X_{\mathrm{e}}\right)
\end{gathered}
$$

そこで，TGの結果をもとに定率乾燥期における乾燥速 度，打よび減率乾燥期間に打ける物質移動係数を算出 し，それぞれ温度と湿度の関数として表した [4]. また， 平衡時の含水率については，前述した水分収着等温線 [1] をもとに，温度抢よび湿度の関数とした [4].

工業的なパスタの乾燥工程では，温度と湿度を連続 的あるいは段階的に変化させるプログラム乾燥が用い られる。そこで，TGより得られた物性值および，構築 したモデルと拡散方程式の解析解 [6] を用いて，実際の パスタをプログラム乾燥した際の含水率変化を予測で きるか調べた。その結果，円柱状のパスタであるスパ ゲッティなどを乾燥した際の結果を良好に表すことが できた（Fig. 4)。とくに，本モデルは，定率乾燥期を 考慮しているため，乾燥初期を非常に精度よく予測で きていることがわかる (Fig. 4 inset) [4]，パスタの場合， $0.12 \mathrm{~kg}-\mathrm{H}_{2} \mathrm{O} / \mathrm{kg}-\mathrm{d} . \mathrm{m}$. 程度の含水率になるまで乾燥す

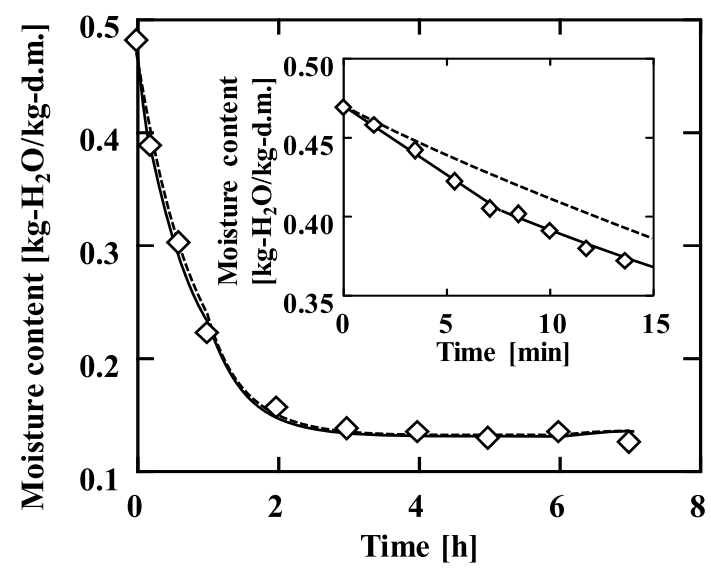

Fig. 4 Comparison of the experimental drying curve with the calculated ones with $(-)$ and without (- - ) considering the constant drying-rate period. Spaghetti (cylindrical pasta) was dried under three-step program conditions: Step 1 is 1 hour at $40^{\circ} \mathrm{C}$ and $60 \% \mathrm{RH}$, step 2 is 5 hours at $60^{\circ} \mathrm{C}$ and $75 \% \mathrm{RH}$, and step 3 is 1 hour at $30^{\circ} \mathrm{C}$ and $60 \% \mathrm{RH}$.

Inset: The extended figure for the early stage of drying.

るが，乾燥終了時刻を推定するには，定率乾燥期の考 慮は必ずしも重要ではない。しかし，乾燥初期には， 非常に速く含水率が低下するため, ひび割れ（クラック） が起こりやすい. クラックの発生は，パスタの品質の 低下につながるため，初期の含水率の制御は重要であ り，そのような意味で定率乾燥期の考慮は必要であろ う。また，収縮はパスタの形状やガラス転移などが関 与する複雑な現象であり [7]，十分に理解されていると はいえない，高精度な含水率の予測は，収縮に起因す るクラックの発生機構を解明するのにも役立つだろう。

\section{3. 沉用的なデジタルカメラを用いた麺の特性評価}

家電として販売されている汎用的なデジタルカメラ は，コストパフォーマンスに優れている，筆者らは， デジタルカメラを用いて，麺の特性を簡便に測定する 手法を 3 つ考案した.

\section{1 表面粗さの定量}

パスタの表面粗さは, 調理 (吸水) の速度やパスタソー スの絡みやすさといった品質に大きく影響する。一般 的に，表面粗さの測定には，接触粗さ計などの接触型 とレーザー走査顕微鏡などの非接触型の 2 種類が用い ら机る。表面が比較的柔らかいパスタの表面観察には, 非接触型の機器が適して打り，国際標準化機構 (ISO) および日本工業規格（JIS）の要件を満たしているレー ザー走査型顕微鏡による測定が好ましい。しかし，現 在ではかなり改善されているようであるが，測定試料 に急傾斜や院影があると，レーザーの反射率の低下や 
遮断が起こるため測定の精度が悪化するという原理的 な欠点が存在する.

表面が粗い物体は，より多くの光を表面で屈折ある いは散乱させる、筆者らは，この点に着目して，デジ タルカメラで撮影したパスタの透過画像をもとに，急 勾配や陰影のある部分を含むパスタであっても，表面 粗さを高い精度で迅速に測定できる方法を開発した [8]. 種々の材質（ブロンズ，アルミニゥム，ポリカー ボネート，ポリプロピレン，テフロン）のダイスで成 型したパスタについて，デジタルカメラで撮影した画 像を Fig. 5 (A)に示す. パスタの伝統的な製法では，ブ ロンズ製のダイスを用いており，このダイスの穴より 射出成型されたパスタの表面は粗くなる. 粗くするこ とで，パスタソースが良く絡むことを期待している. 一方，ブロンズ製のダイスは摩耗が速いこともあり， 近年の工業的な製造では，テフロン製のダイスが主流 である.テフロン製を用いると，パスタの表面は滑ら かになる。

これらのパスタの表面をレーザー走査型顕微鏡で計 測した際の表面粗さの分布（最も深い位置を基準とし た高さの分布）を Fig. 5 (B)に示す.テフロン，ポリプ ロピレン，ポリカーボネート製のダイスで作製したパ スタの表面粗さの分布は, 低い領域でシャープなピー クとなり，アルミニウム製打よびブロンズ製では，高 い領域でブロードなピークとなった.

デジタルカメラで撮影したパスタのカラー画像をモ ノクロ化して, 画像内でパスタが写った範囲を対象に, 輝度值の頻度（ヒストグラム）を算出した。ここで, 輝度值の範囲は 0〜255（黒から白，8ビット）であり, 值が大きいほど白いことを示す（Fig. 5 (C)). 表面が 滑らかなパスタは, 表面での光の散乱が少なく, パス
夕を通り抜けて来る光が均一であるため，より大きな 輝度值を狭い範囲で示した。一方，ブロンズ製打よび アルミニウム製のダイスを用いて作製したパスタは， 表面が粗いため，小さな輝度值を広い範囲で示した. レーザー走査型顕微鏡による粗さ分布とデジタルカメ ラによるヒストグラムを比較すると，双方の形状はよ く一致して扣り，比較的高精度で表面粗さの分布を計 測できることがわかった [8].

\section{2 クラックの定量}

2.2 でも述べたがクラックが生起したパスタは，日本 に拈いて商品価值が著しく下がる。工業的な製造にお いて，製造ラインの始動時などに，非常に稀にクラッ クが生起するようである。従来では，特定パターンを 見つけ出すパターン認識や物体の輪郭を検出するエッ ジ検出といった画像処理アルゴリズムを組み合わせる ことでクラックを検出することが試みられてきた。し かし，ブロンズ製のダイスで作製したパスタは表面が 粗く，一般的に用いられるクラック検出のアルゴリズ ムでは，粗い表面をクラックと誤認識する問題点があ る。そこで, デジタルカメラで撮影したパスタの画像 からクラックのみを検出する手法を開発した [9]. 詳細 は割愛するが, 本手法はパスタをデジタルカメラで撮 影した画像の輝度值のヒストグラムに着目したもので あり，輝度值のヒストグラムの形状的な特徴量をもと にクラックを識別することで，表面の粗いパスタにつ いてもクラックを検出できるようにした.

近年では，人工知能 $(\mathrm{AI})$ の発達により，クラック の生起をはじめとする不良品の選別に AI を用いること が注目を集めている，そのような中で，従来の画像処 理は，時代遅れになっているのかもしれないが， AI と
(A)

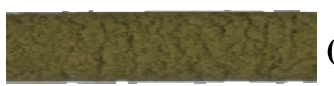

(a)

(b)

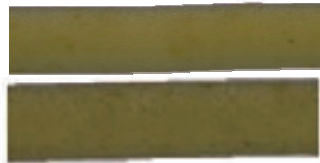

(c)

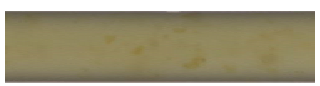

(e)

(d)
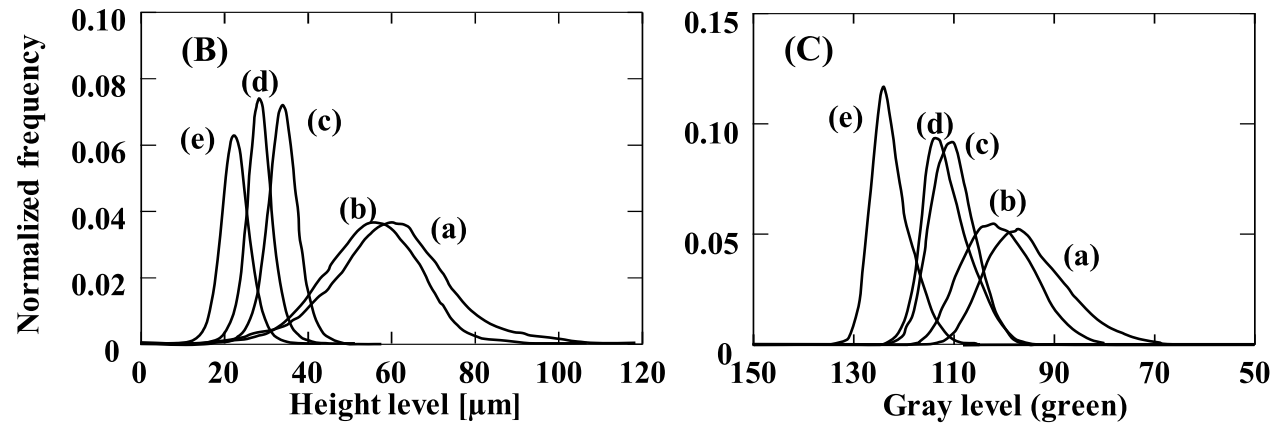

Fig. 5 (A) Transmission images of spaghetti extruded through dies made of (a) bronze, (b) aluminum, (c) polycarbonate, (d) polypropylene, and (e) Teflon. The diameter of each spaghetti was $1.7-1.8 \mathrm{~mm}$. Images were trimmed from their original size to enhance the visualization of surface roughness. (B) Examples of height-level frequency distributions derived from laser scanning microscopy, for spaghetti extruded through dies. (C) Examples of gray-level frequency distributions. 
異なり学習が不要であることは長所であろう。とくに， パスタのクラックのように，発生が稀な現象に対して は，AIに学習させる教師データの収集が課題となる。

\section{3 含水率分布の測定}

乾燥パスタの最適な茹で状態は，アルデンテとよば れ，調理学的には髪の毛 1 本の芯が中心に残った状態 を指す。パスタを吸水させると，水は表面から内部へ と入っていくため，パスタ内部の含水率は一様ではな く，分布が生じる。パスタは含水率の増加にともない, 色が明るくなる、筆者らは，この色の変化にもとづき， パスタ内部の含水率分布を測定する方法を開発した [10]. この方法は，次の 5 つのステップからなる.

最初のステップでは，吸水させたパスタを 2 セット 用意する。 1 セットは含水率分布の測定用であり，もう 1 セットは，色の明るさ（輝度）と含水率を相関させる 検量線の作成用である。検量線を作成するためのパス 夕は，吸水後， $70^{\circ} \mathrm{C}$ で 3 日間静置してパスタ内の含水 率分布を均一にする。 2 番目のステップでは，2セット のパスタを切断し，その断面を上方からデジタルカメ ラで撮影する（Fig. $6(\mathrm{~A})$ ). 3 番目のステップでは，力 ラー画像をモノクロ化する (Fig. 6(B) ). 4 番目のステッ プでは，内部の含水率分布を均一化したセットを用い て，モノクロ画像のグレーレベルと含水率とを相関さ せる検量線を作成する。最終ステップでは，含水率分 布を測定するためのセットについて，検量線をもとに， グレーレベルを含水率に変換する。これにより，パス タ内部の含水率分布を測定することができる.

食品中の含水率分布は，多くの場合，核磁気共鳴画 像 (MRI) 法や中性子ラジオグラフィー法で測定される. 今回開発した装置の空間分解能（約 $3.2 \mu \mathrm{m} ）$ は，MRI 法を使用して得られる空間分解能の約 20 倍であり，原 理的には可視光の波長程度まで高めることができる.
(A)

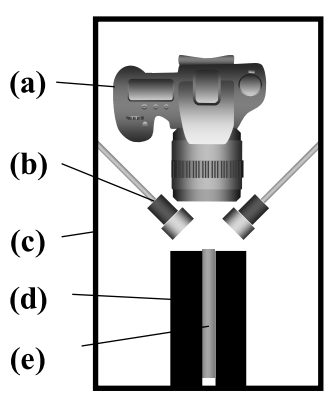

(B)

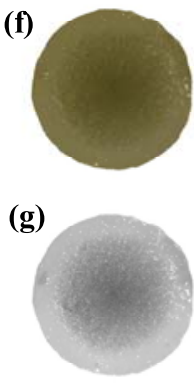

Fig. 6 (A) Schematic diagram of the equipment used for measuring moisture distributions: (a) digital camera, (b) cold light illuminator, (c) illumination box, (d) light shield, and (e) sample. (B) The cross-section images of pasta rehydrated during 10.2 minutes which was acquired using the digital camera (f) and digitally processed $(g)$, respectively.
また，MRI 法では，アルデンテ時の中心部に存在する 含水率が低い領域を原理的に計測することが困難であ る. 本手法は，空間分解能が高いだけでなく，そのよ うな低い含水率についても測定することをはじめて可 能にした.

\section{4. 麺 の 吸 水}

\section{1 吸水挙動}

\subsection{1一定温度下における吸水挙動}

スパゲッティを一定温度で吸水させた際の含水率の 変化を Fig. 7 に示す [11]. パスタ [11-12] やうどん [13-14] といった麺類だけでなく，多くの食品でも同様 の挙動を示す．吸水時間をスパゲッティの直径の 2 乗 で除した值に対して含水率をプロットすると，太さが 異なるスパゲッティ（正確には，太さによってフェデ リーニやスパゲッティーニと呼称が変わる）であって もそれらの吸水挙動は，一本の曲線で表される。後述 するように，吸水は非常に複雑な現象であるが，この 結果は，含水率勾配を駆動力とする拡散がパスタの吸 水挙動に強く関与していること示唆している。これら のことを考慮して，筆者らは次式を用いて吸水挙動を 解析した。

$$
X=\frac{a \times\left(t / d^{2}\right)}{b+\left(t / d^{2}\right)}+X_{0}
$$

上記の式は双曲線型であり，吸水初速度（ $t=0$ のとき の速度）は $a / b$ となり,最大の含水率 (平衡時の含水率) $X_{\mathrm{e}}$ は $a+X_{0}\left(a\right.$ は初期の含水率 $X_{0}$ より十分に大きいの で $a+X_{0} \approx a$ と近似できる）で表すことができる．吸水 初速度 $a / b$ と平衡時の含水率 $a$ の温度依存性を Fig. 8 に示す [11]. 吸水初速度 $a / b$ は，低温から高温にかけ てアレニウス型の温度依存性を示し，近似直線の傾き より算出した活性化エネルギーは $30.5 \mathrm{~kJ} / \mathrm{mol}$ であっ た。一方で, 平衡時の含水率 $a$ は, その温度依存性（Fig.

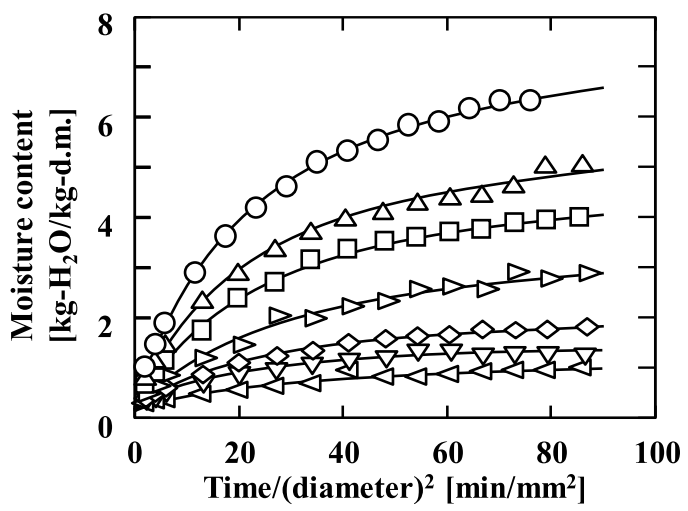

Fig. 7 Rehydration of spaghetti at $(\bigcirc) 90^{\circ} \mathrm{C},(\triangle) 80^{\circ} \mathrm{C}$, $(\square) 70^{\circ} \mathrm{C},(\triangleright) 60^{\circ} \mathrm{C},(\diamond) 55^{\circ} \mathrm{C},(\nabla) 50^{\circ} \mathrm{C}$, and $(\triangleleft)$ $20^{\circ} \mathrm{C}$. Curves are calculated to best-fit the observed moisture contents to eq. (3). 


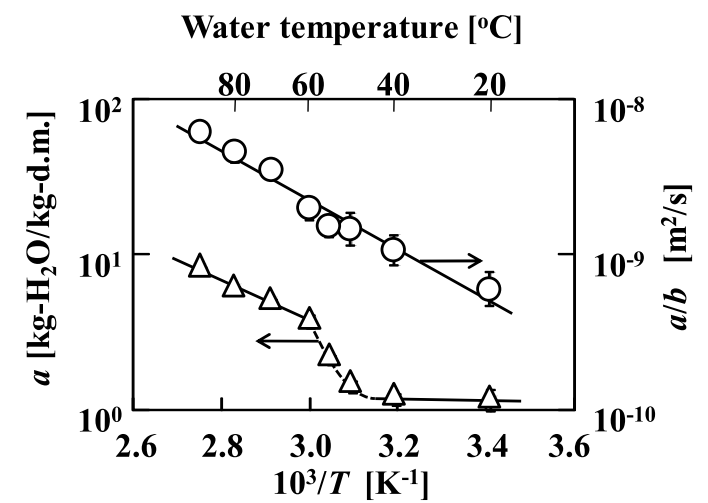

Fig. 8 Temperature dependencies of $(\triangle)$ the equilibrium moisture content $a$ and $(\bigcirc)$ the initial rate of rehydration $a / b$.

8 に打けるプロットの傾き） から約 $40^{\circ} \mathrm{C}$ 以下の低温領 域, 約 $40 \sim 60^{\circ} \mathrm{C}$ の遷移領域, 約 $60^{\circ} \mathrm{C}$ 以上の高温領域に 分けられ，低温領域と高温領域のそれぞれにおける近 似直線の傾きより算出した吸水のエンタルピー変化は, 1.44 と $25.1 \mathrm{~kJ} / \mathrm{mol}$ であった。このスパゲッティを示差 走查熱量計 $(\mathrm{DSC})$ で測定すると, 糊化開始温度 $\left(T_{\text {onset }}\right)$ と糊化ピーク温度 $\left(T_{\text {peak }}\right)$ は，それぞれ 45.3 と $60.5^{\circ} \mathrm{C}$ とそれぞれ遷移領域の開始温度と終了温度とほぼ一致 する.

\subsection{2 吸水溶液中の塩の影響}

工業的に製造される多くのパスタは，うどんなどと 異なり，加水した小麦粉（デュラムセモリナ）に食塩 を添加しない，その代わり，吸水時に $0.5 \sim 1 \%(\mathrm{w} / \mathrm{v})$ の食塩水を用いる。種々の濃度の塩溶液で吸水させた 際の含水率を時間に対してプロットすると, Fig. 7 と同 様に, 双曲線型の式(3)でよく表すことができ，塩濃度 が高くなるほど，含水率は低下した [15]。しかし，実 際に食する塩濃度程度では，大きな差はみられないよ うである。

塩の添加が吸水挙動に及ぼす影響を調べるために, 喫食はできないが，食塩の他に塩化リチウムと塩化力 リウムの溶液などで吸水試験を行った。 そして，無限 円柱に対する拡散方程式の解析解をもとに，見かけの 拡散係数を算出した。用いた塩は溶液中で電離してい ると考えられ, 塩化物イオンは共通であることから， 各カチオンの結晶半径 $\left(\mathrm{Li}^{+}<\mathrm{Na}^{+}<\mathrm{K}^{+}\right)$に対して見かけ の拡散係数をプロットした (Fig. 9). 結晶半径が大き くなるほど，見かけの拡散係数が大きくなり，矛盾し ているようであった，一方，水和を考虑すると各カチ オンの半径（ストークス半径）の大きさは, 結晶半径 とは逆の順番となる $\left(\mathrm{Li}^{+}>\mathrm{Na}^{+}>\mathrm{K}^{+}\right)$，穴のため, ストー クス半径に対して見かけの拡散係数をプロットすると， ストークス半径が大きくなるほど，パスタの吸水は遅 くなるという妥当な結果が得られた。ただし，この見 かけの拡散係数は, カチオンの挙動を直接的に表すも

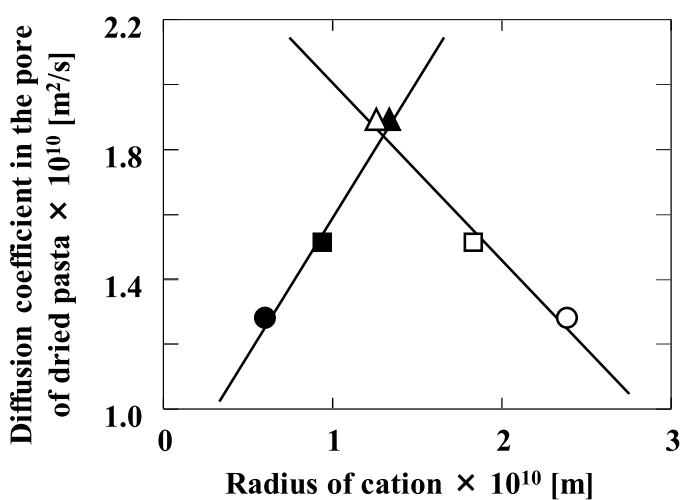

Fig. 9 Relationships between the apparent diffusion coefficient at $60^{\circ} \mathrm{C}$, the crystalline radius (closed symbols) and the Stokes radius (open symbols) for $(\bigcirc) 1.83$ $\mathrm{mol} / \mathrm{L} \mathrm{LiCl},(\square) \mathrm{NaCl}$, and $(\triangle) \mathrm{KCl}$ solutions.

のではないことに注意されたい。

\subsection{3 パスタの表面粗さの影響}

テフロン製のダイスで作製したパスタの表面は，一 見滑らかであるが，顕微鏡で拡大すると Fig. 10 の内図 のように，凹凸が認められる．3.1で述べたが，ブロン ズ製のダイスで作製したパスタは表面が粗い。種々の 材質で作製したスパゲッティを円柱と仮定して算出し た単位表面積あたりの初期の吸水量は，表面が粗いほ ど大きい（Fig. 10 に○で示す）[16]．しかし，表面の 凹凸を考慮して，単位表面積あたりの初期の吸水量を 計算すると, 表面の粗さに依存しないことがわかる (Fig. 10 に○で示す)．ダイスの材質が異なると，押出し時に パスタに加わる圧力は変わるが，糊化温度や平衡時の 含水率には影響を及ぼさなかった [17]. ブロンズ製の ダイスで作製したパスタは，テフロン製のパスタと比 較すると，最適な含水率まで吸水するのに要する時間 が約 1 分短い。このような時間の短縮は，茹で水と接 する表面積が増えたことに起因するようである。

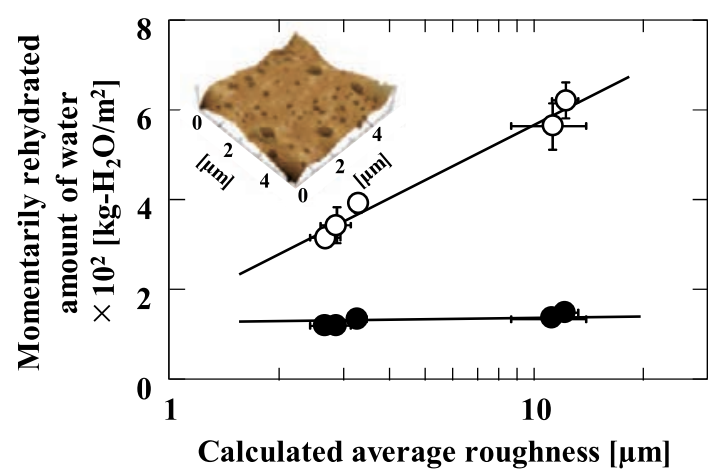

Fig. 10 Dependence of the momentarily rehydrated amounts of water per unit area for $(\bigcirc)$ smooth and $(0)$ rough on the calculated average roughness. Inset: AFM image of the surface of spaghetti extruded through Teflon die [22]. 


\subsection{4 定速昇温下における吸水挙動}

4.1.1に打いて，平衡時の含水率の温度依存性から, パスタの糊化温度を把握できることを解説した。この 方法では，一定の温度で吸水しているため，温度を変 えて複数回，吸水試験を実施する必要がある。そこで 筆者らは，吸水の温度を直線的に上げていく，定速昇 温条件を採用することで，1回の吸水試験から糊化温度 を簡略的に計測することを考案した [18]．異なる昇温 速度で吸水した場合の含水率の変化を Fig. 11 に示す. 含水率は，ある時間（温度）を境に急増し，それぞれ 時間に正比例した直線で近似できる。この 2 本の直線 の交点温度を計測すると，それらはDSCによる糊化開 始温度と糊化ピーク温度の中間に位置した（Fig. 11 inset)。糊化温度は，測定法により多少の差異がみられ るため，本手法により得られた糊化温度は，妥当であ ると考える。

\section{2 吸水機構の推定}

前述したように，パスタを吸水すると内部には含水 率の分布が形成される。前項までに解説した吸水挙動 の解析に打いては，この分布を考慮せずに，平均的な 含水率を用いている。平均的な值からであっても，非 常に多くの有用な情報を得ることができるが，やはり “平均的”であって，詳細な吸水機構を考究するには， パスタ内部に打ける水の移動を調べることが不可欠で ある。

3.3 で解説した測定法を用いて，乾燥パスタを吸水し た際の含水率分布の経時変化を調べたところ，従来の拡 散モデルをもとに予測されていた含水率分布と形状がか なり異なって打り，次のようなユニークな特徵がみられ た（Fig. 12） [10]. すなわち，(1)吸水後の全ての含水率

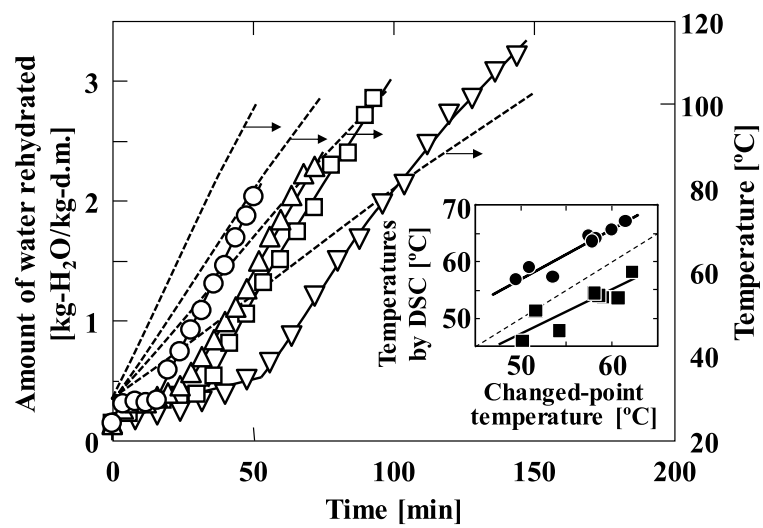

Fig. 11 Rehydration curves for spaghetti at the different temperature-raising rates. The temperature-raising rates were $(\nabla)$ 0.50, $(\square)$ 0.77, $(\triangle) 1.00$, and $(\bigcirc) 1.38{ }^{\circ} \mathrm{C} / \mathrm{min}$.

Inset: Relationships of the ( $\square$ ) onset and (O) peak temperatures in differential scanning calorimetry (DSC) and the changed-point temperature by the proposed method for the 8 different noodles.

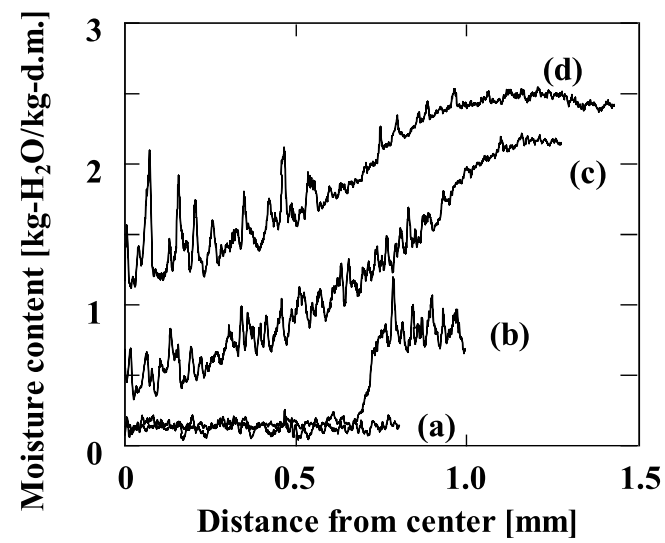

Fig. 12 Moisture distributions of spaghetti rehydrated for (a) 0 , (b) 1 , (c) 10.2 , and (d) $20 \mathrm{~min}$.

分布の形状に幅が 10〜 $40 \mu \mathrm{m}$ 程度の細かな凹凸が認めら れた。 (2) 1 分間吸水した初期に打いて，表面付近のみで 含水率が急激に上昇した。 (3) 10 分以降の吸水後期では 表面付近に含水率がほぼ一定の領域がみられた。(4)熱水 と接する表面の含水率が徐々に増加した。

デュラムセモリナ中の澱粉の粒径は，2４0 $\mu \mathrm{m}$ 程度 であり，(1)の含水率分布の細かな四凸の間隔とほぼ一 致する。澱粉粒は，粒径により吸水性が異なることが 知られており，この細かな凹凸は，澱粉粒の不均一な 吸水挙動を反映していると考えられる。本手法では, 測定の空間分解能が従来法に比べて向上したことで, 詳細にパスタ内部に打ける水の移動挙動を計測できる. (2)のような含水率の急激な上昇は，パスタ表面に形成 された非常に小さな（目に見えないような）亀裂に熱 水が入り込み，表面付近の澱粉粒が糊化することで生 起したと考えられる。また，デュラムセモリナに対す るガラス転移曲線 [3] より，この付近でガラス状態から ラバー状態に転移しているようである。従来の拡散モ デルによると，水の移動は含水率勾配を駆動力として おり，(3のように含水率が一定の領域では，水は移動 できず，矛盾が生じる。また，パスタの表面では，熱 水と接しているにも関わらず，その含水率の上昇が非 常に遅いようである。“表面”に打ける吸水挙動を明ら かにするために，“表面”之“太さのない直径が $0 \mathrm{~mm}$ ” が同等とみなせるであろうことに着目し，太さのない 直径が $0 \mathrm{~mm}$ の仮想的なパスタを考えた [19]. しかし， そのようなパスタは存在しないため，さまざまな直径 のパスタの平均含水率を測定し，それらの值に対して， 直径が $0 \mathrm{~mm}$ の方向に外挿することで，太さのない仮 想的なパスタの含水率を推算することを考えた（Fig. 13 inset). 直径 $0 \mathrm{~mm}$ のパスタの含水率は，太さがな いにも関わらず，瞬時に平衡值に到達せず，時間に対 して徐々に増加した (Fig. 13). 次に，デュラムセモリ ナからグルテンを取り出し，グルテンのみからなる麺 を作製して，吸水挙動を調べたところ，先ほどの直径 0 


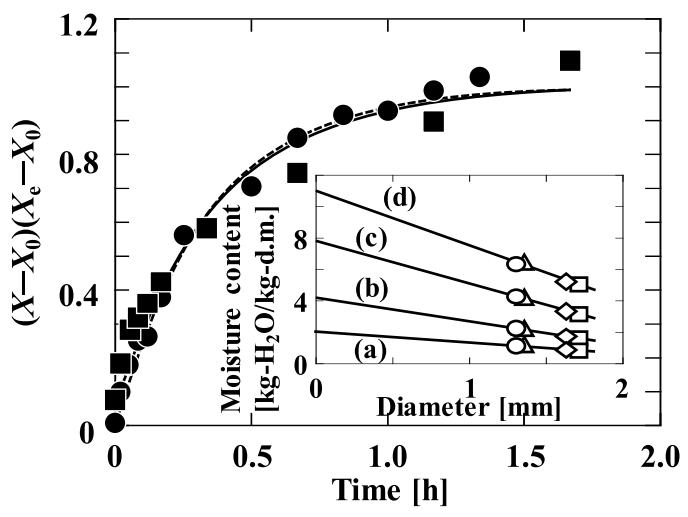

Fig. 13 Changes in the normalized moisture contents for (-0-) $0 \mathrm{~mm}$ pasta and (-- --$)$ gluten pasta. Inset: Estimation of the moisture content of infinitely thin pasta with initial diameters of $(\bigcirc) 1.30,(\triangle) 1.35$, $(\diamond) 1.63$, and $(\square) 1.71 \mathrm{~mm}$ by extrapolation at the rehydration times of (a) 5, (b) 20, (c) 40, and (d) $80 \mathrm{~min}$.

$\mathrm{mm}$ のパスタの吸水挙動と非常によく一致した（Fig. 13)。な打，これらのパスタの平衡時の含水率は異なる ため，Fig. 13 では規格化した含水率でプロットしてい る。高分子であるグルテンは, 吸水によりエネルギー 的に有利な構造を自発的に獲得しようとして，そのネッ トワーク構造が弛緩すると考えられる。このような高 分子の弛緩の進行は非常に緩慢な過程であることが知 られており，グルテンの網目状のネットワークに囲ま れた澱粉粒は，糊化による膨潤が抑制される.

以上のことから，パスタ内部での水の移動機構を推 察すると次のようになる。乾燥パスタには，乾燥時に 生起した非常に小さい（目視では判別できない程度の） 亀裂があり，熱水に浸漬すると即座に，この亀裂から 熱水が入り込む。熱の移動は速いため，パスタの温度 は中心部であっても，比較的短時間のうちに熱水の温 度まで到達して，ガラス状態からラバー状態に転移す る. 糊化の速度は, 拡散のそれに比べて非常に速いため, 表面付近の亀裂から供給される熱水は，その近傍の澱 粉の糊化に使用され，パスタ内部へは届かない。その ため，吸水初期には，表面より少し内側に急激な含水 率分布の段差が形成されると考えられる。しかし，含 水率の勾配が非常に大きいため, 拡散により水は中心 部へと徐々に移動するようになる。一方，パスタ内部 では，澱粉粒がネットワーク状のグルテンに取り囲ま れており，澱粉粒は拡散によって移動してくる水を利 用して速やかに糊化・膨潤しようとするが，周りのグ ルテンがその膨潤を抑制する。律速となっているグル テンのネットワークが弛緩すると，そこに内包されて いる澱粉粒が即座に水を取り込むため，パスタの表面 付近では含水率が一定の領域が生じ，含水率の勾配が なくても含水率が上昇すると考えられる，さらに，吸 水した澱粉は，膨潤するため，含水率が一定の領域が
広がっていく，このように，パスタは吸水の進行にと もない，膨張していくが，表面と中心とでは含水率に 勾配が生じるため，この勾配を駆動力とする拡散によ り，水はゆっくりと内部に移動していく，それにより， 中心付近では，放物線に近い含水率分布を形成すると 考えられる。

\section{3 含水率分布と食感}

麺を茹で過ぎるとコシがなくなるというように，含 水率分布は食感を決定する重要な因子であるが，含水 率分布と食感の関係は十分にわかっていない。そこで 筆者らは，種々の条件で吸水させたパスタの含水率分 布と，クリープメーターを用いた破断試験で得られる 破断応力抢よび破断歪率の関係を調べた [20-21]. 吸水 の温度 $\left(60^{\circ} \mathrm{C}, 80^{\circ} \mathrm{C}, 100^{\circ} \mathrm{C}\right)$ が異なると，同一の平均 含水率となるまで吸水させてもそれらの含水率分布は 異なり，高温ほど，パスタの表面と中心部の含水率の 差が増大する傾向がみられた (Fig. $14(\mathrm{~A}-\mathrm{a}))$ ） そして, 高温で吸水するほど，破断応力は増大したが，破断歪 み率は同じであった（Fig. 14 (A-b))。一方，実際の調 理に使用する濃度としては現実的ではないが，吸水溶 液中の食塩濃度 $(0,0.1 ， 1.0,2.0 \mathrm{~mol} / \mathrm{L})$ を大きく変 えて, 同様に, 同一の平均含水率となるまで吸水させ ても，4種類の麺の含水率分布は重なった（Fig. 14 $(\mathrm{B}-\mathrm{a}))$.これらのパスタの破断応力は, ほぼ同一であっ たが，塩濃度が高くなるほど，破断歪み率は低下した (Fig. $14(\mathrm{~B}-\mathrm{b}))$. 以上の結果より，低い含水率領域に 応じて大きな破断応力を示すこと，吸水溶液中の食塩 濃度が増大するほど小さな破断歪率を示すこと，含水 率分布は，破断応力に独立して影響を及ぼすことがわ かった。 これらの知見は，必ずしもすべての吸水条件 で成り立つとは限らないが，食感を制御するうえで重 要であろう。

\section{5. 乾燥および吸水現象が品質に及ぼす影響}

前述したように，工業的なパスタの乾燥工程では， 温度と湿度を連続的あるいは段階的に変化させるプロ グラム乾燥が用いられる。温度と湿度は，乾燥後ある いは喫食時の品質に影響を及ぼすと考えられるが，こ のようなプログラム乾燥における温度と湿度の組み合 わせは膨大となる。そのため，所望する品質となる最 適な乾燥工程の設計は，非常に困難を極める.

筆者らは，まず，異なる 3 種類のプログラム乾燥（最 高温度が $\left.50^{\circ} \mathrm{C}, 70^{\circ} \mathrm{C}, 85^{\circ} \mathrm{C}\right)$ で作製したスパゲッティ について，種々の品質（乾燥直後の色，表面構造，食 感特性，ならびに吸水後の破断特性，ソースの絡み度） を調べた [22]。その後，より詳細に温度と湿度の影響 を明らかにするために，恒温恒湿条件（温度 : 50, 70, 


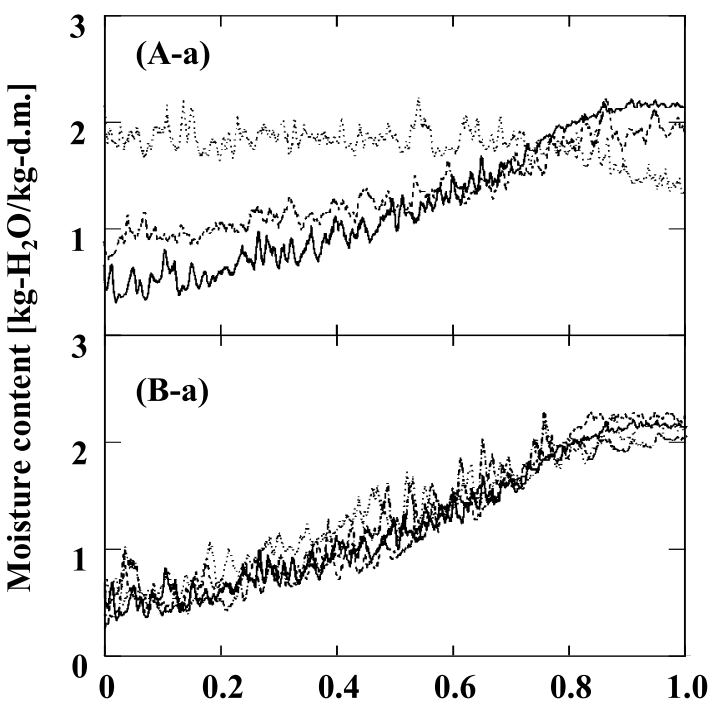

Normalized distance from center [ - ]

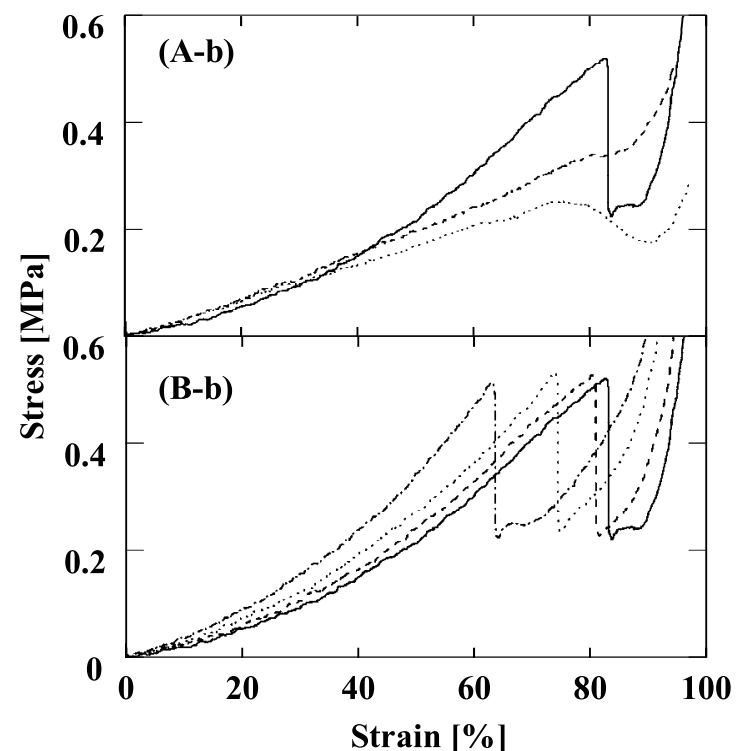

Strain $[\%]$

Fig. 14 (A-a) Moisture distributions and (A-b) representative examples of stress-strain curves for spaghetti rehydrated at $(\cdots) 60^{\circ} \mathrm{C},(--) 80^{\circ} \mathrm{C}$, and $(-) 100^{\circ} \mathrm{C}$ in distilled water. (B-a) Moisture distributions and $(\mathrm{B}-\mathrm{b})$ representative examples of spaghetti rehydrated at $100^{\circ} \mathrm{C}$ in $(-)$ distilled water, $(--) 0.1 \mathrm{~mol} / \mathrm{L} \mathrm{NaCl}$ solution, $(\cdots) 1.0 \mathrm{~mol} / \mathrm{L} \mathrm{NaCl}$ solution, and $(-\cdot) 2.0 \mathrm{~mol} / \mathrm{L} \mathrm{NaCl}$ solution.

$85^{\circ} \mathrm{C}$ ，湿度：50，60，70，80\% RH）で乾燥した 12 種 類のスパゲッティについて，上記と同様に，種々の品 質を調べた [23]. 本稿では，ソースの絡み度について のみ解説する。ソースの絡み度については，デキスト ラン溶液を仮想的なソースとして用い，1本のスパゲッ ティが保持できる量からソースの絡み度を推算する装 置を考案した（Fig. 15）。ソースの絡み度は，乾燥状態 のスパゲッティ表面の粗さが必ずしも重要ではなく, 吸水後のスパゲッティの 2 バイトテクスチャー試験 (Texture Profile Analysis : TPA) から得られる付着性 と負の相関がみられた。TPA 試験では，クリープメー ターを用いて試料を 2 回圧縮した際の応力と歪みの関

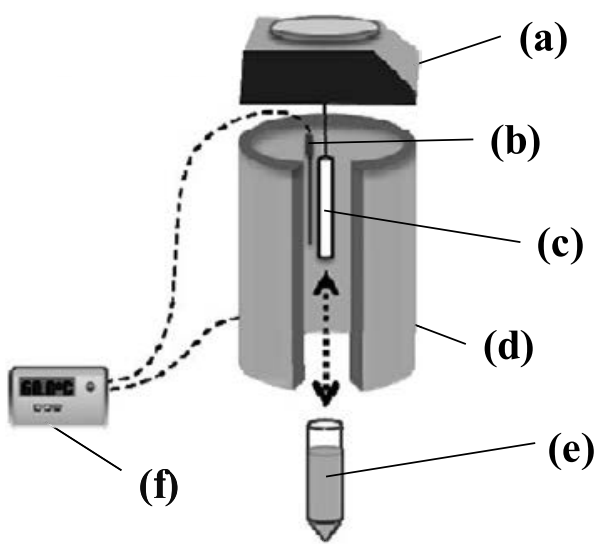

Fig. 15 Schematic diagram of the equipment used for measuring the sauce retention of differentially dried, cooked spaghetti. (a) balance, (b) thermocouple, (c) sample, (d) heating mantle, (e) sauce, and (f) temperature controller.
係（応力-歪み曲線）を計測し，付着性はこの応力 - 歪 み曲線において，1 回目の圧縮直後の引っ張り過程で応 力が負となる領域の面積と定義される．付着性にはス パゲッティ内部からのアミロースの溶出が関与してお り，低温で乾燥するほど，酵素が失活しないため，吸 水時のアミロースの溶出量が増大するといわれている. つまり，吸水時にスパゲッティから溶出したアミロー スは，表面に薄いゲル状の膜を形成し，表面を滑らか にするため，ソースの絡み度を低下させると考えられ る。ただし，アミロースは，脂質やタンパク質，多糖 と相互作用を示すことが報告されており [24]，使用す るソースとの相性も重要であろう.

以上の研究で得られた知見が，パスタに留まらず, 多くの食品の品質を合理的に設計するための乾燥打よ び吸水技術の開発に繋がると幸いである.

\section{6. 現在までの取り組みと今後の展望}

本稿では，麺の乾燥挙動，デジタルカメラを用いた 麺の特性評価, 麺の吸水挙動, 乾燥および吸水が麺の 品質に及ぼす影響について解説した。 とくに,まず, デュ ラムセモリナに対して水分子が単層から多層に吸着し ていく過程で，水の部分モル体積が倍増するため，乾 燥したパスタ中の水は，バルク中のそれとかなり性質 が異なることが示された。また，定率乾燥期とその後 の減率乾燥期での乾燥挙動を区別して記述することで, 任意の条件（温度，湿度扎よび時間）で乾燥した際の パスタの平均含水率を高精度に予測するモデルを提案 した．次に，汎用的なデジタルカメラであっても，簡 
便にパスタの表面粗さの計測やクラックの検出ができ るだけでなく，高価な専用の測定機器に勝る精度でパ スタ内部の含水率分布を計測できることがわかった。 さらに, 吸水時の平均含水率を測定することで, 例えば, 澱粉の糊化状態などを把握できることが示された。ま た，パスタ内部の含水率分布の経時的な変化を可視化 することで，非常にユニークな水の移動挙動を見出し， それをもとに水の移動機構を推察した。最後に，乾燥 および吸水挙動が, 食感やソースの絡み度などの品質 に及ぼす影響について検討した。

以上のように，はじめは水の移動挙動に着目して研 究を進めてきたが，食感などの品質を検討するうえで, グルテンの重要性を改めて認識するに至った．とくに グルテンは構造が鍵であり，多くのグループが研究し てきたが，3次元的な構造については，不明な点が多く 残されている。そこで筆者らは，麺などの食品を透明 にする新たな試薬を開発し，多光子蛍光顕微鏡を用い ることで，麺内部のグルテンの構造をはじめて 3 次元 的に可視化できるようにした．この透明化試薬は，米 粒を透明化することもでき，ライトシート顕微鏡で計 測することで，米粒内部のタンパク質の分布を 1 細胞 レベルの空間分解能でまるごと解析することができる. さらに，バーチャルリアリティー技術を活用すること で，あたかも麺や米粒の内部に飛び込んだかのように， 計測した 3 次元構造を可視化する技術も開発している. また，透明化手法を用いることで，食品内部の構造に ついて，高速かつ大量に高精細な画像を取得できるよ うになり，構造の解析に人工知能 (AI) を使用できる ようになった。構造とそれに対応する食感を AIにあら かじめ学習させることで, AI が未知の構造であっても 食感を予測できる可能性を見出している。そして， AI が学習した内容を解析することで，食感に影響を及ぼ す構造について，これまで人間が気付かなかったよう な興味深い知見が得られることがわかってきた [25]. 特定の食感を決定するような鍵となる構造が存在する のか？あるいは，構造が複数組み合わさることではじ めて特定の食感を生み出しているのか？など，まだま だ不明なことは多いが，AI な゙も活用しながら，食品 研究に微力ながら尽力していきたい.

\section{謝辞}

本受賞対象となった研究は，京都大学大学院農学研 究科食品生物科学専攻農産製造学分野に扎いて行った ものです．本研究を行う機会を与えていただき，学生 の時から終始温かくご指導とご鞭撻を賜りました京都 大学名誉教授・京都先端科学大学特任教授 安達修二先 生に心より感謝申し上げます。本研究テーマは，学部 4 年時の課題研究 (卒業論文) の際にいただいたもの
です。はじめは 1 年間だけ取り組むつもりでしたが, 安達先生にご指導いただきながらの研究にのめり込み, 気が付けばあっという間に 11 年が経ちました。途中で 麺を扱うテーマから遠のいた時期もありましたが，こ の間に行った数々の研究はどれも思い入れがあるもの ばかりです。その中でもとくに，デジタルカメラを用 いて含水率分布を測定する手法は，アイディアと工夫 次第でブレイクスルーを生み出せることを知れた大変 よい体験でした。このように，新たなアイディアを出 すことで課題を解決していく楽しさは, 安達先生に教 えていただいた数多くのことの中の 1 つであり，現在 に打いても研究・教育に取り組むうえでの大きな原動 力となっています。また，常に的確なご助言を賜りま した先生方，研究の遂行をサポートしていただきまし たスタッフの皆様，ともに実験や議論をしてくださっ た卒業生扎よび在学生の皆様に感謝申し上げます。本 研究の一部は, コンソーシアム形式で企業との共同研 究として行ったものであり，その参加メンバーであっ た京都大学大学院農学研究科教授 松村康生先生, 准教 授 林 由佳子先生, 助教 松宮健太郎先生, 岐皁大学大学 院連合農学研究科教授 西津貴久先生，ならびに企業の 多くの方々に厚く御礼申し上げます。また，松村康生 先生には, 博士課程修了後, 研究員として受け入れて いただき， 2 年半にわたりご指導を賜りました。 それま での食品工学的な手法に加えて, 食品化学的な手法を 学ぶことができた貴重な期間であり, 前述の透明化溶 液の開発につながりました。京都大学大学院農学研究 科教授 谷史人先生には，現在，日々の研究・教育活動 に対するきめ細やかなお気遣いとご指導，ご支援を賜っ ております. AIなどを用いた研究と並行して,生化学的・ 分子生物学的な手法を教わることで, より研究の幅を 広げ，新たな展開を図ることができているように思い ます．この場を措りして厚く御礼申し上げます。

食品の製造プロセスは，依然として熟練技術者の経 験や試行錯誤の繰り返しに頼っている部分が多いよう ですが，それは裏を返せば，それだけ積みあげられた 先人達の知恵が素晴らしいことの証左であるように思 われます。この度，幸運にも奨励賞を賜ったことに感 謝しつつ，「コロンブスの卵」的な発想を大切にしなが ら，先人達が築き上げられた学術基盤をもとに，一歩 ずつ着実に発展させる一助となれるよう邁進していく 所存です。これからも日本食品工学会の皆様の温かい ご指導のほど，何卒よろしくお願い申し上げます.

\section{NOMENCLATURE}
$a:$ parameter in Eq. $3, \mathrm{~kg}-\mathrm{H}_{2} \mathrm{O} \cdot \mathrm{kg}^{-1}$-dry matter
$b$ : parameter in Eq. $3, \mathrm{~s} \cdot \mathrm{m}^{-2}$
$d$ : diameter, $\mathrm{m}$ 
$k:$ mass transfer coefficient, $\mathrm{m}^{2} \cdot \mathrm{s}^{-1}$

$L$ : thickness, $\mathrm{m}$

$R_{\mathrm{w}}:$ drying rate, $\mathrm{kg} \cdot \mathrm{m}^{-2} \cdot \mathrm{s}^{-1}$

$S$ : drying area, $\mathrm{m}^{2}$

$t$ : time, s

$w:$ dry weight of the sample, $\mathrm{kg}$

$X$ : moisture content at time $t, \mathrm{~kg}-\mathrm{H}_{2} \mathrm{O} \cdot \mathrm{kg}^{-1}-\mathrm{d}$.m.

$X_{0}$ : initial moisture content at $t=0, \mathrm{~kg}-\mathrm{H}_{2} \mathrm{O} \cdot \mathrm{kg}^{-1}-\mathrm{d}$.m

$X_{\mathrm{e}}$ : equilibrium moisture content, $\mathrm{kg}-\mathrm{H}_{2} \mathrm{O} \cdot \mathrm{kg}^{-1}-\mathrm{d}$.m.

\section{References}

1) A. Chuma, T. Ogawa, T. Kobayashi, S. Adachi; Moisture sorption isotherm of durum wheat flour. Food Sci. Technol. Res., 18, 617-622 (2012).

2) A. Hasegawa, T. Ogawa, S. Adachi; Dilatometric measurement of the partial molar volume of water sorbed to durum wheat flour. Biosci. Biotechnol. Biochem., 77, 1565-1568 (2013).

3) B. Cuq, C. Verniere; Characterisation of glass transition of durum wheat semolina using modulated differential scanning calorimetry. J. Cereal Sci., 33, 213-221 (2001).

4) T. Ogawa, T. Kobayashi, S. Adachi; Prediction of pasta drying process based on a thermogravimetric analysis. J. Food Eng., 111, 129-134 (2012).

5) T. Ogawa, S. Koizumi, S. Adachi; Thermal analysis of drying process of durum wheat dough under the programmed temperature-rising conditions. Food Bioprod. Process., 92 9-13 (2014).

6) J. Crank; The mathematics of diffusion, 1st ed., Oxford U. P., Oxford, UK, 1975.

7) N. Mizuno, T. Ogawa, S. Adachi; Shrinkage and tensile stress of sheet-like and cylindrical pastas with various moisture contents. Food Biosci., 2, 10-14 (2013).

8) T. Ogawa, S. Adachi; A simple method to measure the surface roughness of spaghetti using a digital camera. Food Sci. Technol. Res., 23, 237-240 (2017).

9) T. Ogawa, S. Adachi; Detection of cracks in dried spaghetti using transmission images. Biosci. Biotechnol. Biochem., 81, 750-754 (2017).

10) T. Ogawa, S. Adachi; Measurement of moisture profiles in pasta during rehydration based on image processing. Food Bioprocess Technol., 7, 1465-1471 (2014).

11) T. Ogawa, T. Kobayashi, S. Adachi; Water sorption kinetics of spaghetti at different temperatures. Food Bioprod. Process., 89, 135-141 (2011).

12) U. Aimoto, T. Ogawa, S. Adachi; Water sorption kinetics of spaghetti prepared under different drying conditions. Food Sci. Technol. Res., 19, 17-22 (2013).
13) T. Roppongi, T. Ogawa, S. Adachi; Water sorption kinetics of wheat noodle with different diameters. Food Sci. Technol. Res., 20, 241-246 (2014).

14) K. Katsuki, T. Ogawa, S. Adachi; Water sorption kinetics of wheat flour noodles with added chemically-modified starch. Starch - Stärke, 70, 1700280 (2018).

15) T. Ogawa, S. Adachi; Effect of salts on the water sorption kinetics of dried pasta. Biosci. Biotechnol. Biochem., 77, 249-252 (2013).

16) T. Ogawa, S. Adachi; Effect of surface roughness on rehydration kinetics of spaghetti. Jpn. J. Food Eng., 15, 101-104 (2014).

17) M. Yoshino, T. Ogawa, S. Adachi; Properties and water sorption characteristics of spaghetti prepared using various dies. J. Food Sci., 78, E520-525 (2013).

18) A. Hasegawa, T. Ogawa, S. Adachi; Estimation of the gelatinization temperature of noodles from water sorption curves under temperature-programmed heating conditions. Biosci. Biotechnol. Biochem., 76, 2156-2158 (2012).

19) T. Ogawa, A. Hasegawa, S. Adachi; Effects of relaxation of gluten network on rehydration kinetics of pasta. Biosci Biotechnol. Biochem., 78, 1930-1934 (2014).

20) T. Ogawa, S. Adachi; Moisture distribution and texture of spaghetti rehydrated under different conditions. Biosci. Biotechnol. Biochem., 80, 769-773 (2016).

21) T. Ogawa, S. Adachi; Effects of drying conditions on moisture distribution in rehydrated spaghetti. Biosci. Biotechnol. Biochem., 78, 1412-1414 (2014).

22) T. Ogawa, A. Chuma, U. Aimoto, S. Adachi; Characterization of spaghetti prepared under different drying conditions. J. Food Sci., 80, E1959-1964 (2015).

23) T. Ogawa, A. Chuma, U. Aimoto, S. Adachi; Effects of drying temperature and relative humidity on spaghetti characteristics. Drying Technol., 35, 1214-1224 (2017).

24) A. M. Hermansson, K. Svegmark; Developments in the understanding of starch functionality. Trends Food Sci. Technol., 7, 345-349 (1996).

25) T. Ogawa; Visualization of the three-dimensional structure inside noodles by clearing and prediction of food texture using artificial intelligence (in Japanese). Foods \& Food Ingred. J. Jpn., 224, 286-295 (2019).

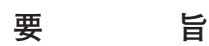

乾燥過程および吸水過程における食品中の水の移動 挙動は，製造時打よび調理時の条件によって大きく異 なり，その挙動により，食品の品質は大きな影響を受 ける。経験と試行錯誤に多くを頼ってきた既存の製造 法では，近年の健康志向や美味しさへの飽くなき追求 
といった多様な要求に対して，迅速かつ的確に応える ことが困難である。爷のため，合理的な食品製造を可 能にする体系的な理論研究が強く求められてきた。し かし, 水の移動現象と移動機構, それらが食感などの 品質に及ぼす影響については，必ずしも十分に解明さ れていないように思われる。筆者らは，粗挽きの小麦
粉であるデュラムセモリナのみからなり，組成が単純 なパスタを研究対象として, 乾燥打よび吸水過程で生 起する水の移動現象とその機構，品質への影響を調心゙ てきた，本論文では，これまでに得られた筆者らの知 見について解説した. 